Article

\title{
Palaeo-Shoreline Configuration of the Adventure Plateau (Sicilian Channel) at the Last Glacial Maximum
}

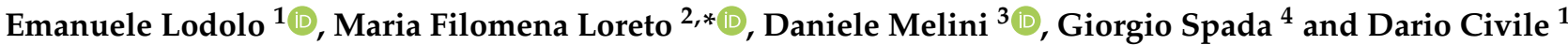 \\ 1 Istituto Nazionale di Oceanografia e di Geofisica Sperimentale-OGS, 34010 Trieste, Italy; \\ elodolo@inogs.it (E.L.); dcivile@inogs.it (D.C.) \\ 2 Istituto di Scienze Marine, Consiglio Nazionale delle Ricerche-CNR, 40129 Bologna, Italy \\ 3 Istituto Nazionale di Geofisica e Vulcanologia, 00143 Roma, Italy; daniele.melini@ingv.it \\ 4 Dipartimento di Fisica e Astronomia (DIFA), University of Bologna, 40127 Bologna, Italy; \\ giorgio.spada@unibo.it \\ * Correspondence: filomena.loreto@bo.ismar.cnr.it
}

\section{check for}

updates

Citation: Lodolo, E.; Loreto, M.F.;

Melini, D.; Spada, G.; Civile, D.

Palaeo-Shoreline Configuration of the Adventure Plateau (Sicilian Channel)

at the Last Glacial Maximum.

Geosciences 2022, 12, 125. https://

doi.org/10.3390/geosciences12030125

Academic Editors:

Adolfo Maestro-González,

Markes E.Johnson and

Jesus Martinez-Frias

Received: 20 January 2022

Accepted: 4 March 2022

Published: 8 March 2022

Publisher's Note: MDPI stays neutral with regard to jurisdictional claims in published maps and institutional affiliations.

Copyright: (c) 2022 by the authors. Licensee MDPI, Basel, Switzerland. This article is an open access article distributed under the terms and conditions of the Creative Commons Attribution (CC BY) license (https:// creativecommons.org/licenses/by/ $4.0 /)$.

\begin{abstract}
The Adventure Plateau, located in the NW sector of the Sicilian Channel, experienced several episodes of exposure/erosion and subsequent drowning, with the most recent occurring after the Last Glacial Maximum (LGM). Unlike other parts of the Sicilian Channel, the Adventure Plateau is relatively tectonically stable and is therefore best suitable for reconstructing its coastal configuration before the post-LGM marine transgression. Here, we use high-resolution seismic data to identify and map the palaeo-coastline at the LGM on the basis of the internal architecture of the prograding wedges (i.e., the location of the subaqueous clinoform rollover point) and the erosional markers such as the subaerial unconformities and the wave ravinement surfaces. These data, which show an extreme variability in the palaeo-morphology of the coastal margins of the Adventure Plateau, have been complemented with vintage seismic profiles in order to entirely cover its perimeter. The mapped LGM coastline has then been compared to predictions from glacial isostatic adjustment (GIA) modeling, which considers the horizontal migration of the shorelines in response to sea level rise and to Earth's rotational and deformational effects associated with deglaciation. The two shorelines (i.e., the coastline derived from the marine data interpretation and the one derived from the GIA model) are in good agreement at 21 kyears BP, although some discrepancies occur in the southern part of the plateau, where the seabed slope is extremely gentle, which makes the clinoform rollover points and the buried erosional unconformities difficult to detect. After 20 kyears BP, an acceleration in the rate of the sea level rise occurred. The results of this study indicate the importance of comparing experimental data with model predictions in order to refine and calibrate boundary parameters and to gain a better picture of the evolution of sea level rise over various time scales.
\end{abstract}

Keywords: Sicilian Channel; Adventure Plateau; high-resolution seismic profiles; glacial isostatic adjustment modeling; Last Glacial Maximum; clinoform rollover point; palaeo-shoreline configuration

\section{Introduction}

The Last Glacial Maximum (LGM), defined as the most recent time period when the continental ice sheets reached their maximum total mass, coincided with a global sea level minimum. According to [1], the growth of ice sheets commenced at 33 kyears BP, and maximum coverage was between 26.5 and 19-20 kyears BP, when deglaciation started in the Northern Hemisphere, causing an abrupt rise in sea level. A large number of proxy records for relative sea level from far-field sites, as well as independent estimates of eustatic sea level changes, show that global sea level during the LGM was 120-135 m lower than present [2]. Between the LGM and the beginning of the Holocene, the deglaciation was characterized by the occurrence of some episodes of exceptionally rapid sea level rise, known as meltwater pulses [3-5]. These episodes have also been identified in the Mediterranean Sea [6], albeit with lower magnitude, thus highlighting their global occurrence. 
Identifying the geomorphological indicators of past sea level in offshore areas is more complex than in emerged areas. This is substantially because the data coverage in marine areas is generally scarce and for the most part not homogeneous, and above all, the clues associated with the position of the palaeo-coastline manifest themselves with very different characteristics, even for relatively nearby areas, or can be lacking due to erosion. In order to reliably identify the internal architecture of the LGM prograding wedges and the erosional surfaces associated with the drowning, high-resolution sub-bottom seismic profiles are essential, but these are often only partially available for the continental shelf areas. Furthermore, these morphological features and markers are often difficult to identify, especially in very-low-gradient areas. A further complication in the reconstruction of the trend of the palaeo-coastlines derived from the interpretation of geophysical data is linked to the presence of vertical tectonic movements (i.e., subsidence or uplift) that must be carefully evaluated and corrected.

Palaeo-shorelines formed during the late Quaternary glacio-eustatic sea level change have the highest potential to have been preserved on the modern shelf. Particularly with the onset of the LGM, which includes Marine Isotope Stage 2 (MIS 2), stable shelves were emergent if not shallower and, depending on offshore gradients, narrower than present, with coastal oceanographic regimes and shoreline sedimentary environments markedly different from the present [7].

Several studies conducted both along the coastal areas of the Italian peninsula and in the circum-Mediterranean shelves highlighted the importance of analyzing the relict sequences of past morphogenetic processes associated with glacial and interglacial climatic phases. The combination of geomorphological and sedimentological analyses, coupled with remote sensing techniques, has allowed for the reconstruction of past landscapes [8] and aided in understanding the genesis and evolution of particular landforms and sea floor features, as well as in inferring relative sea level changes and their influence on coastal landscape evolution [9].

In this paper, the coastline trend at the LGM has been reconstructed for the entire Adventure Plateau, which is the shallowest sector of the Sicilian Channel (Figure 1). The choice of this sector derives from the fact that it is the only area where we have the availability of high-resolution seismic data (sparker and chirp profiles) along the entire perimeter of the plateau. Furthermore, this area does not present evidence of vertical tectonics, at least starting from the late Pliocene, if we exclude its north-easternmost edge, and therefore, it is suitable for a reliable reconstruction of its palaeo-geographic setting.

The palaeo-shoreline, mapped through the interpretation of high-resolution seismic data, is compared with the palaeo-shoreline derived from the glacial isostatic adjustment (GIA) model. This approach allows us to verify the reliability of the interpretation by superimposing the two coastal profiles (i.e., the one obtained from the interpreted data and the other provided by the model) and to highlight possible discrepancies that may reveal limitations in the modeling. 


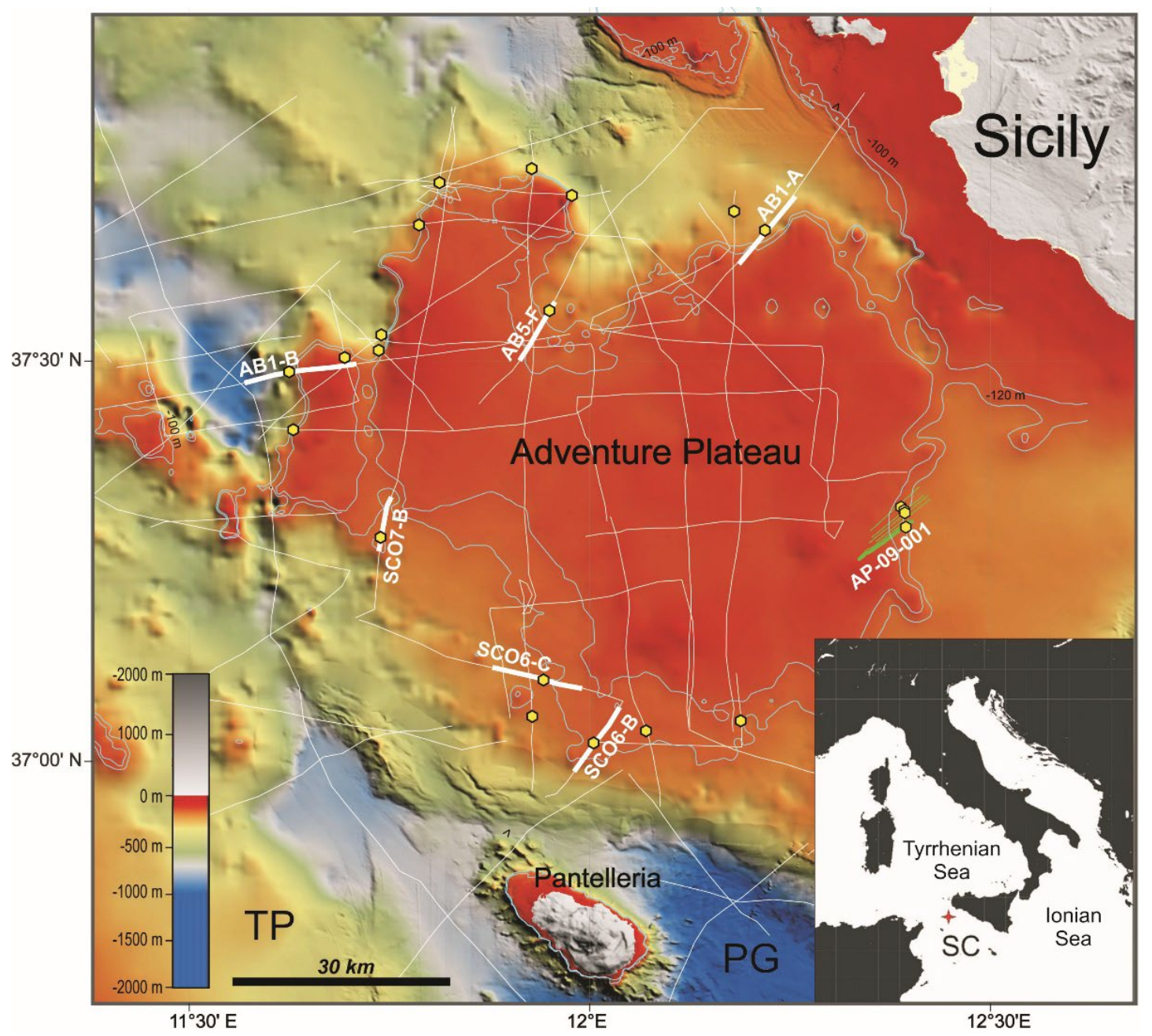

Figure 1. General morpho-bathymetric map of the northwestern Sicilian Channel. Background bathymetry taken from http:/ / www.emodnet-bathymetry.eu/ (accessed on 7 December 2018), on which recently acquired multibeam swaths have been superimposed. The digital elevation model (DEM) for land areas has been produced by gridding the SRTM90 data (http:/ / www.cgiar-csi.org/) (accessed on 1 July 2013). Bathymetry contours of -100 and $-120 \mathrm{~m}$ water depths are shown (light blue lines). Yellow dots indicate the locations where the palaeo-shoreline at the LGM has been identified from high-resolution geophysical profiles. Thick white segments refer to the corresponding sparker profiles presented in Figure 3. Green segment refers to the chirp profile presented in Figure 3. Box at the lower right corner shows the location of the study area (red star). TP: Tunisian Plateau; PG: Pantelleria graben; SC: Sicilian Channel.

\section{Morphology and General Geological Setting of the Adventure Plateau}

The $\sim 8000 \mathrm{~km}^{2}$ Adventure Plateau, located in the northwestern part of the Sicilian Channel, is morphologically and structurally limited by regions where water depths exceed $250 \mathrm{~m}$. To the north, the plateau is separated from Sicily by a relatively deep channel (water depths of about $120 \mathrm{~m}$ ), and to the south, it is separated from the Tunisian Plateau by the rift-related Pantelleria graben (maximum water depths of about $1300 \mathrm{~m}$ ). To the west and east, its morphological edges are more articulated and mostly associated with relatively steep scarps. The stratigraphic succession of the Adventure Plateau, reconstructed by the analysis of several available exploratory wells that in some cases reached depths of $5 \mathrm{~km}$, is similar to that known for the other shallow areas of the Sicilian Channel, as it is part of the same continental platform. It is composed of a Triassic-Eocene predominantly carbonate succession and of a mostly siliciclastic Oligocene-Quaternary sequence [10]. The 
highly tectonized sedimentary substratum outcrops at the sea floor form shallow banks which rise up to less than $10 \mathrm{~m}$ below sea level [11]. In addition to sedimentary banks, the Adventure Plateau is also punctuated, in its northern and eastern parts, by several Quaternary volcanic edifices [12-14]. Analysis of seismic reflection profiles, combined with sedimentation rates and the curve of global eustatic sea level change, showed that during the LGM, the Adventure Plateau formed a large peninsula protruding into the Sicilian Channel, separated from the North African coastline by less than $50 \mathrm{~km}$ [15]. The gradual increase in the sea level caused the flooding of most of the peninsula, with the exception of the morphological highs that, until around early Holocene time, formed an archipelago of several islands separated by stretches of shallow sea [16-18]. Available sedimentary cores have shown that the shoals of the Sicilian Channel are covered, for the most part, by a considerably reduced, unconsolidated bioclastic layer [19]. Radiocarbon dating indicates that oceanographic conditions affecting the sea floor changed significantly between the late Pleistocene and the early Holocene, as well as that non-deposition and/or erosion have prevailed since about 10,000 years BP [20].

Analyses of geomorphological markers indicate that the western sector of Sicily is tectonically stable (the calculated vertical tectonic rate is $\pm 0.04 \mathrm{~mm} /$ year), at least for the periods of the late Pleistocene and the Holocene [21,22]. This is also confirmed by independent measurements derived from semi-permanent GPS stations [23]. The calculated rate, over a period of 20,000 years, translates into a vertical movement of $\pm 0.8 \mathrm{~m}$. Since the Adventure Plateau is part of the same geological province of western Sicily, the contribution of the vertical motion should be comparable in the two regions. Analysis of high-resolution seismic profiles in the Sicilian coastal sector between the cities of Mazara del Vallo and Sciacca has shown that this area has undergone an uplift rate of $\sim 0.6 \mathrm{~mm} / \mathrm{yr}$ in the last 20,000 years [24], which translates to about $\pm 12 \mathrm{~m}$ of vertical movement. Similar values have been reported analyzing morphological elements onshore [25]. This sector of the Sicilian Channel is affected by the Capo Granitola and Sciacca fault systems, which are part of a lithospheric-scale strike-slip fault zone running roughly N-S and crossing most of the Sicilian Channel [26-28]. However, this structure does not significantly influence the tectonic context of the study area since it is located about $20 \mathrm{~km}$ to the east of the margin of the Adventure Plateau on which we have concentrated our analyses.

\section{Materials and Methods}

High-resolution sub-bottom chirp seismic profiles analyzed in this paper were acquired by the R/V OGS Explora during two surveys carried out in 2017 and 2018 as part of the "FASTMIT" research project, coordinated by the Istituto Nazionale di Oceanografia e di Geofisica Sperimentale (OGS) and funded by the Italian Ministry of University and Research (MIUR). Details of the technical characteristics of the used instruments, acquisition parameters and data processing may be found in [14]. Our original bathymetric data were complemented with the freely available EMODnet Digital Bathymetry $(1 / 16 \times 1 / 16$ arcminutes, corresponding to ca. $115 \times 115 \mathrm{~m}$ of lateral resolution, and downloaded from http: / /www.emodnet-bathymetry.eu/) (accessed on 7 December 2018), to cover the areas not surveyed by our dataset. To integrate the chirp data acquired by the R/V OGS Explora for the western and southern part of the Adventure Plateau, we have utilized a series of vintage, $30 \mathrm{~kJ}$ sparker high-resolution seismic profiles acquired in the 1970s and 1980s by the R/V Bannock [29]. These data were acquired as a part of a multidisciplinary project ("Progetto Finalizzato-Oceanografia e Fondali Marini") supported by the Italian National Research Council (CNR) (see Figure 1). The sparker profiles were scanned from the paper format to high-resolution raster images (TIFF) and then converted into geo-referenced SEG-Y standard format using the free MATLAB ${ }^{\circledR}$ program IMAGE2SEGY, following the procedure described in [30]. This allowed us to perform the interpretation with the Kingdom ${ }^{\circledR}$ software package (IHS Markit). Furthermore, considering that the navigation at the time used the Loran-C system, which later converted into the ED50 coordinates system through a non-automatic procedure, the position was converted into 
UTM Zone 33 (WGS84 system), associating the navigation points to the corresponding SEG-Y profiles uploaded into the Kingdom ${ }^{\circledR}$ software. Considering the method applied to retrieve the sparker profiles, it is clearly understandable that this vintage dataset has significantly lower quality and resolution than the chirp profiles. However, to date, these sparker records represent the only useful information available for our purposes in this sector of the Sicilian Channel.

On the seismic profiles acquired along the perimeter of the Adventure Plateau, we have identified a high-amplitude and continuous reflector associated to the combination of: (i) a subaerial erosion (subaerial unconformity, SU) that marks the landscape exposed at the moment of the maximum marine regression (i.e., the minimum of the sea level corresponding to the MIS 2) and (ii) the subsequent transgressive reworking surface (wave ravinement surface, WRS) that develops progressively landward during shoreface retreat due to wave action [31-33]. The SU+WRS surfaces are generally recognizable on seismic profiles by their planar geometry over large horizontal distances, the erosive truncation of the underlying strata and the superposition of sedimentary beds often characterized by a sub-horizontal or gently dipping stratal geometry. The pattern of the SU+WRS surfaces can vary from flat to very irregular due to several factors, the most important being the inherited topography of the substrate and lateral variations of waves energy and the differential resistance to erosion of the bedrock [33]. Figure 2 shows two representative high-resolution profiles where the LGM unconformity, produced by subaerial erosion (SU) and subsequent wave action (WRS) during the sea level rise, and the truncated prograding wedge, associated with the rapid sea level fall, can be recognized. Along these seismic profiles, it is possible to locate the position of the LGM palaeo-shoreline. In particular, the geographic location of the ancient coastline at the LGM has been mapped at the subaqueous clinoform rollover point at the seaward termination of the SU+WRS unconformity [31]. In some seismic profiles, these specific features are difficult to identify since the original shoreline was likely reworked/eroded by the wave action during the landward migration of the shoreface. In areas characterized by very low gradients, where the rollover points are often not recognizable, we have combined seismic data with high-resolution bathymetric information, when available, to identify and map the slope breaks.

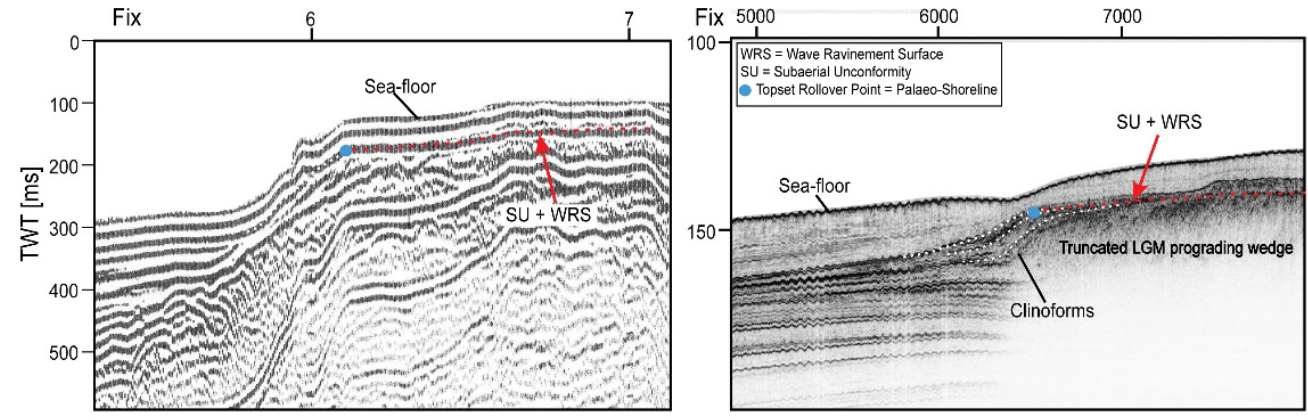

Figure 2. Two representative high-resolution seismic profiles (sparker on the left and chirp on the right) of the Adventure Plateau edges that highlight the morphological and inner geometric characteristics of the truncated prograding wedge and erosional surfaces at the LGM sea level minimum.

Based on these considerations about the difficulty of accurately identifying the rollover point of the clinoforms, as well as the inherent inaccuracies in the conversion of the vintage data we used for the interpretation, we may quantify errors in altitude (i.e., water depths) in the range of about $\pm 6-10 \mathrm{~m}$ and errors in the horizontal plane in the range of about $\pm 1-2 \mathrm{~km}$.

To model the time evolution of the shorelines in the NW Sicilian Channel, we obtained a high-resolution numerical solution of the gravitationally and topographically self-consistent sea level equation (SLE) using the SELEN ${ }^{4}$ solver [34]. The SLE accounts for deformational, gravitational and rotational effects induced by spatio-temporal variations 
of ice and meltwater loads $[35,36]$. We implemented in SELEN ${ }^{4}$ an ice-sheet chronology according to the ICE-7G GIA model by [37-39], which is based on a spherically symmetric earth model with Maxwell rheology whose viscosity varies with depth. The SLE has been solved on a global icosahedral grid with spatial resolution of about $40 \mathrm{~km}$ and inclusion of harmonic terms up to Lmax $=512$, which correspond to a minimum wavelength of about $78 \mathrm{~km}$. To prescribe the present-day global topography as a final condition for the numerical solution of the SLE, we employed the bedrock version of the ETOPO1 global topographic model by [40], which has been integrated with the Bedmap2 relief on the Antarctica region (e.g., below $60^{\circ} \mathrm{S}$ latitude).

\section{LGM Morphological Signature of the Adventure Plateau Margins}

The interpretation of high-resolution seismic and bathymetric data follows the procedure described in [24], and we refer the reader to that publication for further details. Compared to that publication, here, a larger dataset is used which covers all the edges of the Adventure Plateau, integrating recent data with vintage ones, in order to produce a more complete and exhaustive palaeo-geographic picture of the area at the LGM sea level minimum. The water depth range taken into account is between -100 and $-130 \mathrm{~m}$ (corresponding to $\sim 0.13$ to $0.17 \mathrm{~s}$ TWT in the seismic profiles, assuming an averaged acoustic velocity of $1560 \mathrm{~m} / \mathrm{s}$ for pore-saturated sediments), because this depth interval includes the (forced regression) prograding wedge associated with the sea level fall and therefore the LGM palaeo-shoreline. The most representative profiles showing the morphology and the geometric characteristics of the margins of the Adventure Plateau are reported in Figure 3.

In general, the northern margin of the Adventure Plateau is characterized by a sharp shelf break, as illustrated by two profiles crossing the margin in its eastern and western parts (Figure 3D,F). This feature is also highlighted by the proximity of the contour lines of the -100 and $-120 \mathrm{~m}$ water depths. Only along the central sector of the northern margin, where there is a southward indentation, is the slope extremely gentle and the shelf break not recognizable (Figure 3B). Moving towards the southern part of the Adventure Plateau, the seafloor morphology is generally quite gentle, with an average slope value of $0.2 \%$ between the -120 and $-100 \mathrm{~m}$ isobaths. Profiles in Figure 3C,E show the general morphology of the margin in this sector. This trend, however, is not fully respected because a sharp slope change is observed in the sparker profile of Figure 3A located at the southeastern corner of the Adventure Plateau. The eastern margin of the plateau has been imaged by the high-resolution chirp seismic profile in Figure 3G, where a palaeo-coastal cliff is present along with a series of landward morphological steps. In this case, the roughness of the inherited physiography (e.g., presence of fault-generated or wave-cut terraces, ridge-andswale topography, rock formations with different resistance to erosion, etc.) is relevant in the driving and conditioning processes preceding the marine transgression.

In several cases, highly deformed and inclined horizons cut by erosional unconformities and covered by sub-parallel layers are seen on seismic data (Figure 3B,D-F). The location of the rollover points of the prograding wedges, which identify the palaeo-coastline along all the seismic profiles, is indicated with a yellow thick arrow in Figure 3. 

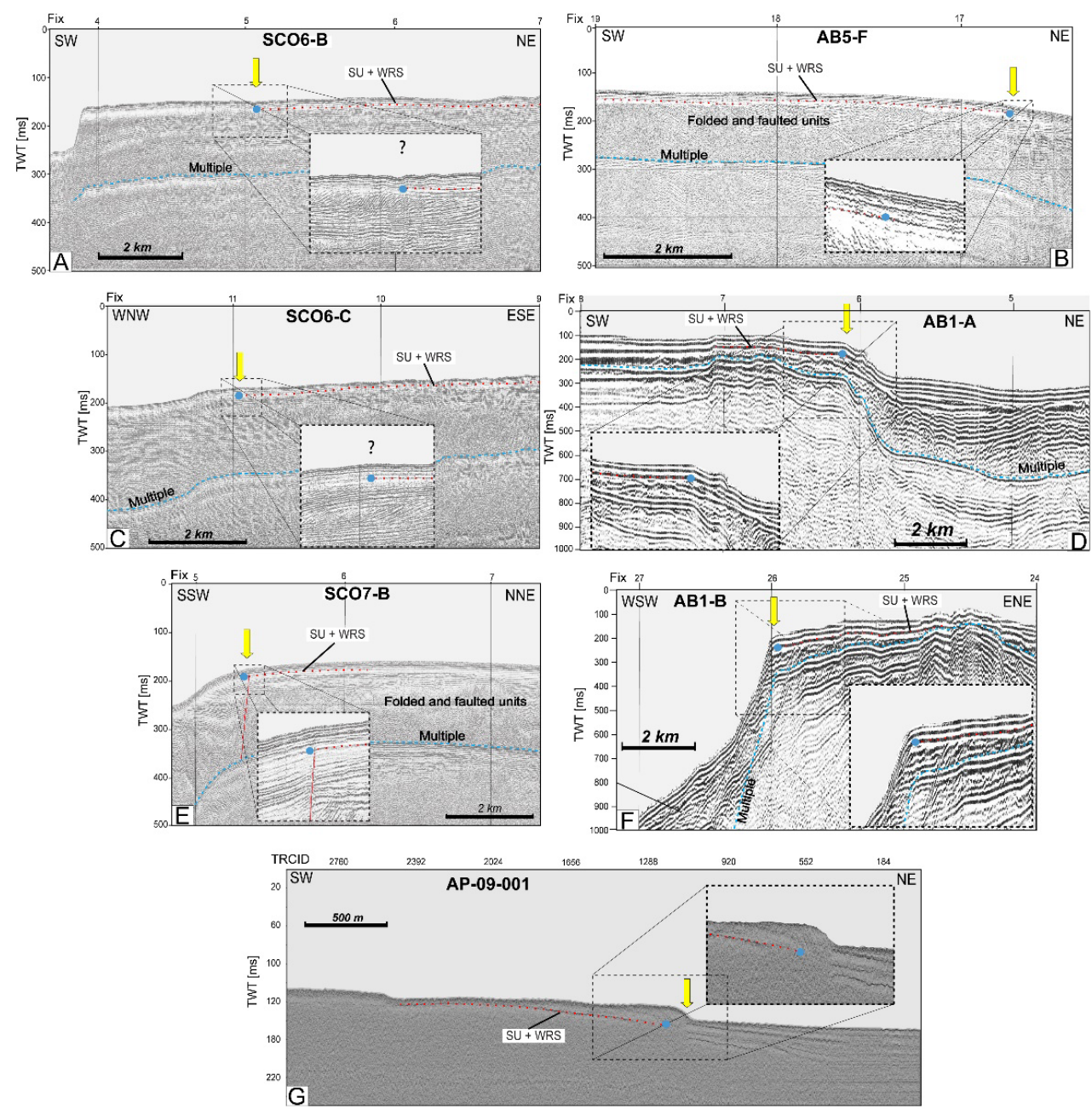

Figure 3. High-resolution seismic profiles acquired along the margins of the Adventure Plateau (see Figure 1 for location). See text for the description of the individual profiles (A-G). Yellow arrows indicate the mapped geographic locations (corresponding to the yellow dots in Figure 1) of the coastline at LGM, where the subaqueous clinoform rollover points have been identified (blue dots).

\section{Palaeo-Coastline Produced by the GIA Model}

From the global solution of the SLE for the ICE-7G GIA model, we obtained a set of snapshots of relative sea level RSL in the study area at different epochs. By virtue of the palaeo-topography equation [34], RSL maps can be combined with the presentday digital topographic models in order to reconstruct the palaeo-topography in the NW Sicilian Channel. On land areas, we employed the same ETOPO1 global relief model [40] used in the solution of the SLE, while at sea, for better accuracy, we used the EMODnet bathymetry. Figure 4 shows the RSL and corresponding palaeo-topography at the 21 kyears $\mathrm{BP}$ snapshot, for which the average modeled topography on the reconstructed shoreline turns out to be closest to zero. We remark, however, that our modeled palaeo-topography only accounts for GIA and does not include tectonic movements that could possibly affect the Adventure Plateau. 

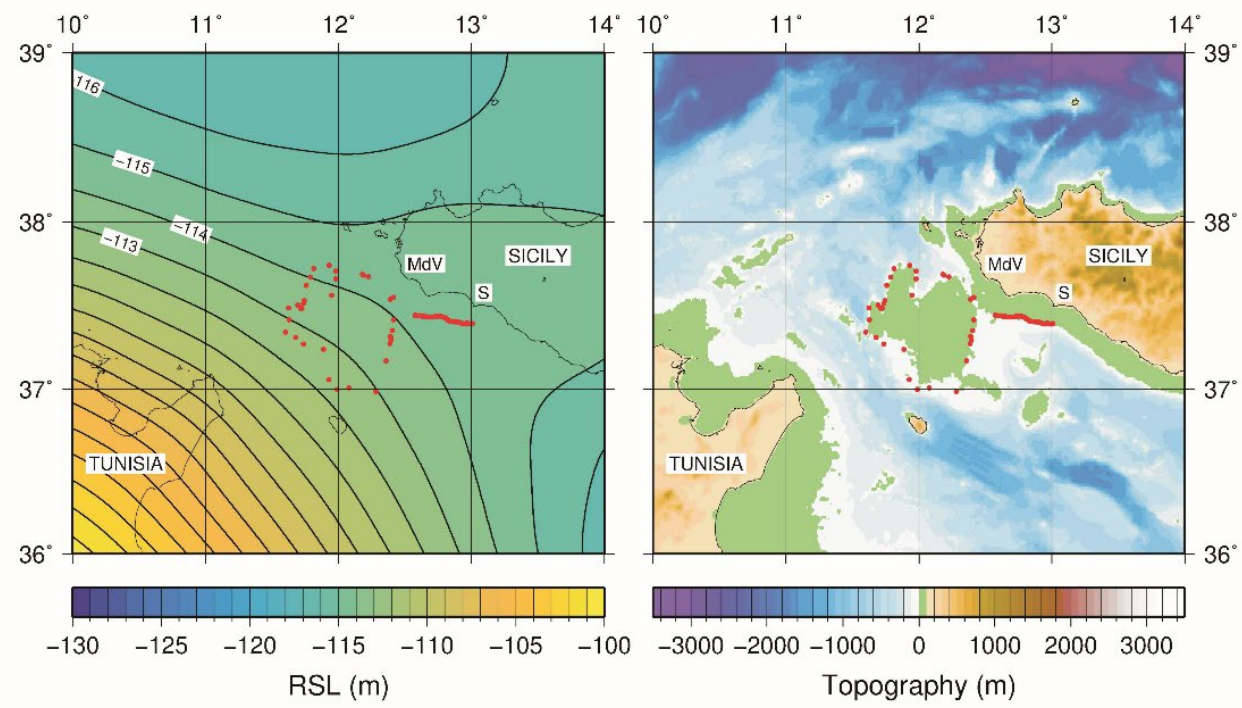

Figure 4. Relative sea level (RSL, left) and palaeo-topography (right) at 21 kyears BP, according to the predictions based on the GIA model ICE-7G [37-39], obtained with the SELEN ${ }^{4}$ solver. The palaeo-topography has been constructed by integrating the RSL map with the EMODnet bathymetry offshore and with the ETOPO1 global relief model [40] on land. Mdv: Mazara del Vallo; S: Sciacca.

Red dots in Figure 4 mark locations of the palaeo-coastline derived from the geophysical interpretation discussed above. Along the coastal area between Mazara del Vallo and Sciacca, locations of the palaeo-coastline have been taken from [24]. We note that model ICE-7G has been shown by [39] to be generally consistent with the relative sea level records from various locations across the Mediterranean Sea, which motivates our choice of the model for this palaeo-geographic reconstruction.

From Figure 4, a quite good overlap can be noted between the GIA-modeled coastline and the observed topography at 21 kyears BP, except for the southern part of the Adventure Plateau, where in general, the bathymetric slope is quite gentle. Slope values along this margin of the plateau calculated in the water depth ranging from -100 to $-130 \mathrm{~m}$ vary from a minimum of $0.16^{\circ}(0.27 \%)$ to a maximum of $0.25^{\circ}(0.43 \%)$. A rise in sea level of $30 \mathrm{~m}$ on a surface of these slopes would cause an inland migration of the coastline of $\sim 15 \mathrm{~km}$ and $\sim 12.5 \mathrm{~km}$, respectively. Local phenomena linked to the presence of relict morphologies or particular localized coastal dynamics may of course strongly influence the magnitude of this landward migration.

These changes in the ancient landscape due to the marine drowning have been much less marked along the edges characterized by more pronounced slopes, where the landward movement of the shoreline was relatively slow and the process of ravinement (erosion by wave action) at the shoreface required more time to rework and redeposit sediments. In addition, we can say that in areas characterized by low slopes, the seismic profiles often do not show any detectable slope breaks, and it is, in many cases, difficult to identify and accurately map the geometries and erosional features of the sea level lowstand phases. Consequently, a certain error is inevitably introduced in the mapping of the geographic location of the LGM palaeo-coastline, as already stated.

The results deriving from the GIA modeling, combined with the locations of the ancient coasts obtained from the seismic profiles, allow us to evaluate the correspondence between the palaeo-geographic trends obtained by the two methods. This comparison also provides a temporal context, albeit approximate, for the phases of advancement towards land of the coastlines as a function of the rates of sea level rise.

\section{Discussion}

In marine sectors where high-resolution seismic and bathymetric data have sufficient areal coverage and where it is possible to correlate similar morphological and geometric 
elements linked to the LGM sea level lowstand, the trend of the palaeo-coastlines can be confidently traced. From this point of view, the Adventure Plateau is a good candidate for the following reasons: (i) a series of high-resolution marine data that cross most of the plateau's perimeter are available; (ii) the area has not been subjected, at least throughout the Quaternary, to tectonic uplift or subsidence, which considerably complicate the identification on the profiles of the palaeo-coastline morphological markers and introduce significant errors in the reconstructions; and (iii) the edges of the Adventure Plateau are characterized by a morphological variability, with slopes ranging from $<0.15^{\circ}$ to $2.5^{\circ}$. This allows us to recognize and analyze the different geometric and depositional characteristics of the landward advancement of the palaeo-coastline.

However, in the absence of direct age determinations of sediment samples, the configuration of the ancient coastline may be reconstructed only qualitatively, mostly on the basis of the geometries and internal architecture of the prograding wedges and the arrangements of the erosional surfaces identified from seismic data. This temporal indeterminacy can be partially bypassed by comparing the trend of the palaeo-coastlines derived from marine geophysical data to those predicted by GIA modeling, which considers the landward migration of the shorelines in response to sea level rise and to Earth's rotational and deformational effects associated with ice melting. In addition, GIA models allow us to visualize how the geography changed over time due to the progress of flooding and provide important clues as to how the coastal landscape has been transformed. We have seen that there is quite a good overlap in the configuration of the ancient Adventure Plateau coastlines produced by GIA for 21 kyears BP, except for the southern sector of the plateau. It is readily understandable how in regions where the slope is remarkably gentle, the landward migration of the coastline is much more evident than in areas characterized by pronounced escarpments for the same sea level variation. This may explain the discrepancy between the points identified by the analysis of the seismic profiles and those produced by the model, considering the errors introduced in both the seismic record conversion and in the interpretation, as previously described. In fact, for such lowland areas, it is often difficult to identify the morphological features of the lowstand sea level and the recognition of the erosional surfaces. In general, transgressive deposits developed above the wave ravinement surface in such low-gradient settings derive from shoreface erosion or from longshore drift [41]. In these environments, the relative sea level rise causes a more rapid landward shift of the shoreline and a much wider transgressed area. On the contrary, the landward movement of the shoreline across a high-gradient topography during flooding is relatively slow, and the erosion by wave action at the shoreface has more time to rework and redeposit sediments, with a resultant formation of a well-recognizable ravinement surface.

From our numerical solution of the SLE, we estimate that the average palaeo-topography evaluated according to the ICE-7G GIA model at the locations marked by the red dots in Figure 4 is $-2.4 \mathrm{~m},-0.8 \mathrm{~m}$ and $+1.0 \mathrm{~m}$ at 20,21 and 22 kyears BP, respectively. Therefore, we find that in the range between 20 and 22 kyears BP, the average topography is closest to zero for the 21 kyears BP snapshot, and its value is consistent with the palaeo-sea level within the associated uncertainties. We should also point out that GIA models, at both global and regional scales, are intrinsically subjected to uncertainties [34,42], which affect all model predictions, including palaeo-topography. In the Mediterranean Basin, [43] has shown that imperfect knowledge of regional-scale rheological structure can affect reconstructed RSL curves by up to a few meters between 12 and 6 kyears BP.

It is important to underline that for low-gradient areas, the sea level rise following the melting of the last polar ice cap has produced the most dramatic consequences from an environmental point of view, causing the coastline to retreat considerably and thus irreversibly modifying the pre-existing geography.

\section{Conclusions}

- By combining a series of recent and vintage high-resolution marine seismic profiles, the morphological elements linked to the LGM sea level fall in the Adventure 
Plateau (NW Sicilian Channel) were analyzed. This allowed us to map the palaeocoastline at the LGM sea level minimum along the entire perimeter of the Adventure Plateau through the identification of the subaqueous clinoform rollover points composing the prograding wedges associated with the LGM sea level fall and the LGM erosional unconformities.

- In general, the analyzed geophysical data showed an extreme variability in the morphology of the margins of the Adventure Plateau: in some cases, the slope breaks of the plateau are very evident, and in other cases, the slope of the margin is extremely gentle instead, making the recognition of the markers related to the sea level minimum at the LGM more difficult.

- The mapped palaeo-coastline was then compared with the predictions derived from the GIA modeling, which considers the horizontal coastal migration in response to sea level rise. The two coastlines (i.e., the coastline derived from the interpretation of marine data and the one derived from the GIA modeling) are in good agreement at 21 kyears BP, with an average modeled palaeo-topography below the $1 \mathrm{~m}$ level. At 20 kyears BP, the model predicts an average palaeo-topography of $-2.4 \mathrm{~m}$, consistent with the post-LGM acceleration in the rate of sea level rise.

- The results of this study indicate the importance of comparing experimental data with model predictions to get a better picture of the evolution of sea level rise over various time scales.

Author Contributions: Conceptualization and original draft preparation, E.L.; marine data analysis and interpretation, M.F.L. and D.C.; software validation, GIA modeling and conceptual analysis, D.M. and G.S. All authors have read and agreed to the published version of the manuscript.

Funding: This research received no external funding.

Institutional Review Board Statement: Not applicable.

Informed Consent Statement: Not applicable.

Data Availability Statement: Details regarding data supporting reported results can be found directly in the text, where we have indicated the corresponding URLs.

Acknowledgments: The digitization of the vintage sparker dataset has been supported by the RITMARE project. We would like to thank Valentina Ferrante for creating the sparker database and the CNR-ISMAR Institute, who is the owner of the data archive. G.S. is supported by an RFO grant of the Dipartimento di Fisica e Astronomia (DIFA) of the University of Bologna. D.M. is supported by an INGV "Ricerca Libera 2019" grant and by the MACMAP project, funded by the INGV Environment Department. We are grateful to the reviewers for all suggestions and comments that helped us to significantly improve the original manuscript.

Conflicts of Interest: The authors declare no conflict of interest.

\section{References}

1. Clark, P.U.; Dyke, A.S.; Shakum, J.D.; Carlson, A.E.; Clark, J.; Wohlfarth, B.; Mitrovica, J.X.; Hostetler, S.W.; McCabe, A.M. The Last Glacial Maximum. Science 2009, 325, 710-714. [CrossRef] [PubMed]

2. Peltier, W.R.; Fairbanks, R.G. Global Glacial Ice Volume and Last Glacial Maximum Duration from an Extended Barbados Sea Level Record. Quat. Sci. Rev. 2006, 25, 3322-3337. [CrossRef]

3. Fairbanks, R. A 17,000-year glacio-eustatic sea level record: Influence of glacial melting rates on the Younger Dryas event and deep-ocean circulation. Nature 1989, 342, 637-642. [CrossRef]

4. Liu, J.P.; Milliman, J.D. Reconsidering melt-water pulses 1A and 1B: Global impacts of rapid sea level rise. J. Oceanol. Univ. China 2004, 3, 183-190. [CrossRef]

5. Deschamps, P.; Durand, N.; Bard, E.; Hamelin, B.; Camoin, G.; Thomas, A.L.; Henderson, G.M.; Okuno, J.; Yokoyama, Y. Ice-sheet collapse and sea level rise at the Bølling warming 14,600 years ago. Nature 2012, 483, 559-564. [CrossRef] [PubMed]

6. Zecchin, M.; Ceramicola, S.; Lodolo, E.; Casalbore, D.; Chiocci, F.L. Episodic, rapid sea level rises on the central Mediterranean shelves after the Last Glacial Maximum: A review. Mar. Geol. 2015, 369, 212-223. [CrossRef]

7. Brooke, B.P.; Nichol, S.L.; Huang, Z.; Beaman, R.J. Palaeoshorelines on the Australian continental shelf: Morphology, sea level relationship and applications to environmental management and archaeology. Cont. Shelf Res. 2017, 134, 26-38. [CrossRef] 
8. De Giosa, F.; Scardino, G.; Vacchi, M.; Piscitelli, A.; Milella, M.; Ciccolella, A.; Mastronuzzi, G. Geomorphological Signature of Late Pleistocene Sea Level Oscillations in Torre Guaceto Marine Protected Area (Adriatic Sea, SE Italy). Water 2019, 11, 2409. [CrossRef]

9. Savini, A.; Bracchi, V.A.; Cammarosano, A.; Pennetta, M.; Russo, F. Terraced Landforms Onshore and Offshore the Cilento Promontory (South-Eastern Tyrrhenian Margin) and Their Significance as Quaternary Records of Sea Level Changes. Water 2021, 13, 566. [CrossRef]

10. Civile, D.; Lodolo, E.; Alp, H.; Ben-Avraham, Z.; Cova, A.; Baradello, L.; Accettella, D.; Burca, M.; Centonze, J. Seismic stratigraphy and structural setting of the Adventure Plateau (Sicily Channel). Mar. Geophys. Res. 2014, 35, 37-53. [CrossRef]

11. Colantoni, P.; Cremona, G.; Ligi, M.; Borsetti, A.M.; Cati, F. The Adventure Bank (off south-western Sicily): A present day example of carbonate shelf sedimentation. G. Geol. 1985, 47, 165-180.

12. Calanchi, N.; Colantoni, P.; Rossi, P.L.; Saitta, M.; Serri, G. The Strait of Sicily continental rift systems: Physiography and petrochemistry of the submarine volcanic centers. Mar. Geol. 1989, 87, 55-83. [CrossRef]

13. Lodolo, E.; Civile, D.; Zanolla, C.; Geletti, R. Magnetic signature of the Sicily Channel volcanism. Mar. Geophys. Res. 2012, 33, 33-44. [CrossRef]

14. Lodolo, E.; Civile, D.; Zecchin, M.; Zampa, L.S.; Accaino, F. A series of volcanic edifices discovered a few kilometers off the coast of SW Sicily. Mar. Geol. 2019, 416, 105999. [CrossRef]

15. Vai, G.B.; Cantelli, L. Litho-palaeoenvironmental maps of Italy during the last two climatic extremes: Map. 1-Last Glacial Maximum; Map. 2-Holocene climatic optimum, 1:1.000.000 scale. In Proceedings of the 32nd IGC Congress, Florence, Italy, 20-28 August 2004

16. Lodolo, E. When the Sicily Channel was an archipelago. Rend. Online Soc. Geol. Ital. 2012, 21, 1174-1175.

17. Civile, D.; Lodolo, E.; Zecchin, M.; Ben-Avraham, Z.; Baradello, L.; Accettella, D.; Cova, A.; Caffau, M. The lost Adventure Archipelago (Sicilian Channel, Mediterranean Sea): Morpho-bathymetry and Late Quaternary palaeogeographic evolution. Glob. Planet. Change 2015, 125, 36-47. [CrossRef]

18. Civile, D.; Lodolo, E.; Caffau, M.; Baradello, L.; Ben-Avraham, Z. Anatomy of a submerged archipelago in the Sicilian Channel (central Mediterranean Sea). Geol. Mag. 2016, 153, 160-178. [CrossRef]

19. Maldonado, A.; Stanley, D.A. Lithofacies as a function of depth in the Strait of Sicily. Geology 1977, 5, 111-117. [CrossRef]

20. Stanley, D.A.; Maldonado, A.; Stuckenrath, R. Strait of Sicily depositional rates and patterns, and possible reversals of currents in the Late Quaternary. Palaeogeogr. Palaeoclimatol. Palaeoecol. 1975, 18, 279-291. [CrossRef]

21. Ferranti, L.; Antonioli, F.; Mauz, B.; Amorosi, A.; Dai Pra, G.; Mastronuzzi, G.; Monaco, C.; Orrù, P.; Pappalardo, M.; Radtke, U.; et al. Markers of the last interglacial sea level high stand along the coast of Italy: Tectonic implications. Quat. Int. 2006, 145, 30-54. [CrossRef]

22. Antonioli, F.; Ferranti, L.; Fontana, A.; Amorosi, A.; Bondesan, A.; Braitenberg, C.; Dutton, A.; Fontolan, G.; Furlani, S.; Lambeck K.; et al. Holocene relative sea level changes and vertical movements along the Italian and Istrian coastlines. Quat. Int. 2009, 206, 102-133. [CrossRef]

23. Serpelloni, E.; Anzidei, M.; Baldi, P.; Casula, G.; Galvani, A. Crustal velocity and strain-rate fields in Italy and surrounding regions: New results from the analysis of permanent and non-permanent GPS networks. Geophys. J. Int. 2005, 161, 861-880. [CrossRef]

24. Lodolo, E.; Galassi, G.; Spada, G.; Zecchin, M.; Civile, D.; Bressou, M. Post-LGM coastline evolution of the NW Sicilian Channel: Comparing high-resolution geophysical data with Glacial Isostatic Adjustment modeling. PLoS ONE 2020, 15, e0228087. [CrossRef] [PubMed]

25. Ferranti, L.; Pepe, F.; Barreca, G.; Meccariello, M.; Monaco, C. Multi-temporal tectonic evolution of Capo Granitola and Sciacca foreland transcurrent faults (Sicily Channel). Tectonophysics 2019, 765, 187-204. [CrossRef]

26. Civile, D.; Lodolo, E.; Accaino, F.; Geletti, R.; Schiattarella, M.; Giustiniani, M.; Fedorik, J.; Zecchin, M.; Zampa, L. Capo Granitola-Sciacca Fault Zone (Sicilian Channel, Central Mediterranean): Structure vs magmatism. Mar. Pet. Geol. 2018, 96, 627-644. [CrossRef]

27. Civile, D.; Brancolini, G.; Lodolo, E.; Forlin, E.; Accaino, F.; Zecchin, M.; Brancatelli, G. Morphostructural Setting and Tectonic Evolution of the Central Part of the Sicilian Channel (Central Mediterranean). Lithosphere 2021, 2021, 7866771. [CrossRef]

28. Fedorik, J.; Toscani, G.; Lodolo, E.; Civile, D.; Bonini, L.; Seno, S. Structural analysis and Miocene-to-Present tectonic evolution of a lithospheric-scale, transcurrent lineament: The Sciacca Fault (Sicilian Channel, Central Mediterranean Sea). Tectonophysics 2018, 722, 342-355. [CrossRef]

29. Colantoni, P.; Del Monte, M.; Gallignani, P.; Zarudzky, E.F.K. Il Banco Graham: Un vulcano recente nel Canale di Sicilia. G. Geol. 1975, 40, 141-162.

30. Farran, M. Una aplicación informática para la conversión de imágenes de perfiles sísmicos a ficheros en formato SEG Y. Geo-Temas 2008, 10, 1215-1218.

31. Catuneanu, O. Principles of Sequence Stratigraphy; Elsevier: Amsterdam, The Netherlands, 2006; p. 386.

32. Patruno, S.; Helland-Hansen, W. Clinoforms and clinoform systems: Review and dynamic classification scheme for shorelines, subaqueous deltas, shelf edges and continental margins. Earth-Sci. Rev. 2018, 185, 202-233. [CrossRef]

33. Zecchin, M.; Catuneanu, O.; Caffau, M. Wave-ravinement surfaces: Classification and key characteristics. Earth-Sci. Rev. 2019, 188, 210-239. [CrossRef] 
34. Spada, G.; Melini, D. SELEN ${ }^{4}$ (SELEN version 4.0): A Fortran program for solving the gravitationally and topographically self-consistent Sea Level Equation in Glacial Isostatic Adjustment modeling. Geosci. Model Dev. Discuss. 2019, 12, 5055-5075. [CrossRef]

35. Farrell, W.E.; Clark, J.A. On postglacial sea level. Geophys. J. R. Astron. Soc. 1976, 46, 647-667. [CrossRef]

36. Mitrovica, J.X.; Milne, G.A. On postglacial sea level: I. Gen. Theory. Geophys. J. Int. 2003, 154, 253-267. [CrossRef]

37. Roy, K.; Peltier, W.R. Glacial isostatic adjustment, relative sea level history and mantle viscosity: Reconciling relative sea level model predictions for the US East coast with geological constraints. Geophys. J. Int. 2015, 201, 1156-1181. [CrossRef]

38. Roy, K.; Peltier, W.R. Space-geodetic and water level gauge constraints on continental uplift and tilting over North America: Regional convergence of the ICE-6G_C (VM5a/VM6) models. Geophys. J. Int. 2017, 210, 1115-1142. [CrossRef]

39. Roy, K.; Peltier, W.R. Relative sea level in the Western Mediterranean basin: A regional test of the ICE-7G_NA (VM7) model and a constraint on Late Holocene Antarctic deglaciation. Quat. Sci. Rev. 2018, 183, 76-87. [CrossRef]

40. Amante, C.; Eakins, B. ETOPO1 Arc-Minute Global Relief Model: Procedures, Data Source and Analysis; NOAA Technical Memorandum NESDIS NGDC-2; National Geophysical Data Center: Boulder, CO, USA, 2009; pp. 1-19.

41. Cattaneo, A.; Steel, R.J. Transgressive deposits: A review of their variability. Earth-Sci. Rev. 2003, 62, 187-228. [CrossRef]

42. Spada, G.; Melini, D. New estimates of ongoing sea level change and land movements caused by Glacial Isostatic Adjustment in the Mediterranean region. Geophys. J. Int. 2021, 229, 984-998. [CrossRef]

43. Lambeck, K.; Purcell, A.W. Sea level change in the Mediterranean Sea since the LGM: Model predictions for tectonically stable areas. Quat. Sci. Rev. 2005, 34, 1969-1988. [CrossRef] 